\title{
ANALYSIS OF THE “POKÉMON GO” ENVIRONMENT CONSIDERING THE PERVASIVE INFORMATION ARCHITECTURE
}

Irvin Soares BEZERRA ${ }^{\mathbf{1}}$; Dimítri de Araújo COSTA ${ }^{\mathbf{2}}$; Francisco de Assis da SILVA ${ }^{\mathbf{3}}$; Carlos Alberto ISAZA ${ }^{4}$; Geuba Maria Bernardo da SILVA ${ }^{5}$

\begin{abstract}
${ }^{1}$ Substitute Professor in Information Systems and Degree in Computer Science/Universidade Federal da Paraíba (UFPB); Professor in Information Systems/Faculdade Pitágoras; Bachelor in Technology in Internet Systems/Faculdade de Tecnologia de João Pessoa; Master in Information Science/UFPB, Brazil. E-mail: irvin.b@gmail.com

${ }^{2}$ Bachelor and Licentiate in Biological Sciences/UFPB; Master in Ecology and Environmental Monitoring/UFPB; PhD Student in Development and Environment (PRODEMA)/UFPB, Brazil; Sandwich PhD Student in Interdisciplinary Centre of Marine and Environmental Research (CIIMAR), Portugal. E-mail: costa.researcher@yahoo.com.br

${ }^{3}$ Bachelor in Ecology/UFPB; Master in Development and Environment (PRODEMA)/UFPB, Brazil. E-mail: assismandela@gmail.com

${ }^{4}$ Bachelor in Public Accounting of Universidad Del Valle, Colombia. E-mail: carlos0isaza@gmail.com

${ }^{5}$ Bachelor in Ecology/UFPB, Brazil. E-mail: geubasilva@gmail.com
\end{abstract}

\begin{abstract}
In Information Science research related to the use of information has been developed, with influence of information technology and telecommunications. Its development was more accelerated in the post-industrial period when society began to produce a large amount of information. In the 21 st century, access to information through the use of the Internet with smartphones has become something within reach of the population, providing an increase in communication. The objective of this work was to analyze the "Pokémon GO" application, considering the Architecture of Pervasive Information in which, the motivation of the use of this subject was the recent launch of applications for smartphones that use pervasive environments, highlighting the game that became a huge success of downloads and brought a great innovation in the way of play. For the accomplishment of this research, the participant research methodology was adopted, in which the user-researcher interacts directly with the searched object. The collected data were analyzed in a qualitative way. Using the game environment and evaluating the pervasive interaction presented at the threshold between the physical and digital environment, the heuristics described by Resmini and Rosati were considered. In the use of the game were explored the physical environments present in the city of João Pessoa, in addition to the moments of interaction. In the results, the adherence to the proposed heuristics was discussed and these were punctuated as Present, Partially Present and Not Present. Finally, the data were analyzed suggesting improvements both for the game, considering the Pervasive Information Architecture,
\end{abstract}


and for the environment itself.

Keywords: Pervasive computing; Heuristics; Human-Computer Interaction.

\section{ANÁLISE DO AMBIENTE DO “POKÉMON GO” CONSIDERANDO A ARQUITETURA DA INFORMAÇÃO PERVASIVA}

Resumo. Na Ciência da Informação pesquisas relacionadas com a utilização da informação vêm sendo desenvolvidas com influência da informática e telecomunicações. O seu desenvolvimento foi mais acelerado no período pós-industrial em que a sociedade começou a produzir uma elevada quantidade de informações. No século XXI, o acesso à informação por meio do uso da internet por meio dos smartphones tornou-se algo ao alcance da população, proporcionando um aumento da comunicação. Diante desta temática, o presente trabalho teve como objetivo analisar o aplicativo "Pokémon GO", considerando a Arquitetura da Informação Pervasiva em que a motivação da utilização desta temática foi o recente lançamento de aplicativos para smartphones que utilizam ambientes pervasivos, destacando o jogo que se tornou um enorme sucesso de downloads e trouxe uma grande inovação na forma de jogar. Para realização desta pesquisa, adotou-se a metodologia de pesquisa participante, na qual o usuário-pesquisador interage diretamente com o objeto pesquisado. Os dados coletados foram analisados de forma qualitativa. Ao utilizar o ambiente do jogo e avaliar a interação pervasiva apresentada no limiar entre o ambiente físico e digital foram consideradas as heurísticas descritas por Resmini e Rosati. Na utilização do jogo foram explorados os ambientes físicos presentes na cidade de João Pessoa, além dos momentos de interação. Nos resultados discutiu-se a aderência às heurísticas propostas e estas foram pontuadas como Presente, Parcialmente Presente e Não Presente. Por fim, os dados foram analisados, sugerindo-se melhorias tanto para o jogo, considerando a Arquitetura da Informação Pervasiva, como para o próprio ambiente.

Palavras-chave: Computação Pervasiva; Heurísticas; Interação Humano-Computador.

\section{ANÁLISIS DEL AMBIENTE DEL “POKÉMON GO” CONSIDERANDO LA ARQUITECTURA DE LA INFORMACIÓN PERVASIVA}

Resumen. En la Ciencia de la Información las investigaciones relacionadas con la utilización de la información se están desarrollando con influencia de la informática y las telecomunicaciones. Su desarrollo fue más acelerado en el período postindustrial en el que la sociedad comenzó a producir una gran cantidad de información. En el siglo XXI, el acceso a la información a través del uso de Internet por medio de los smartphones se volvió algo al alcance de la población, proporcionando un aumento de la comunicación. En esta temática, el presente trabajo tuvo como objetivo analizar la aplicación "Pokémon GO", considerando la Arquitectura de la Información Pervasiva en que la motivación de la utilización de esta temática fue el reciente lanzamiento de aplicaciones para smartphones que utilizan 
ambientes pervasivos, destacando el juego que se convirtió en un enorme éxito de las descargas y trae una gran innovación en la forma de jugar. Para la realización de esta investigación, se adoptó la metodología de investigación participante, en la cual el usuario-investigador interactúa directamente con el objeto investigado. Los datos recogidos se analizaron de forma cualitativa. Al utilizar el ambiente del juego y evaluar la interacción pervasiva presentada en el umbral entre el ambiente físico y digital fueron consideradas las heurísticas descritas por Resmini y Rosati. En la utilización del juego se exploraron los ambientes físicos presentes en la ciudad de João Pessoa, además de los momentos de interacción. En los resultados se discutió la adherencia a las heurísticas propuestas y éstas fueron puntuadas como Presente, Parcialmente Presente y No Presente. Por último, los datos fueron analizados, sugiriendo mejoras tanto para el juego, considerando la Arquitectura de la Información Pervasiva, como para el propio ambiente.

Palabras clave: Computación Pervasiva; heurística; Interacción Humano-Computadora.

\section{INTRODUCTION}

Studies over time showed that the Information Science (IS) was consolidated in studies about mediation and use of the information within some fields of study and search, some of them are Information Recovery, Communication of Information and Cognition Studies.

Following the use of the digitals systems trend and the focus on information, in 1979 the American architect Richard Saul Wurman used the term Information Architecture (IA) as a way to describe the creation of interfaces for the use of computerized systems (WURMAN, 1997). The Information Architecture is described as a way to outline and create concepts of information for systems that require complex details.

From the 1990s and with the evolution of the digitals systems, new ways of content started to be used. Digital contents and electronic documents, the internet development, the use of hyperlinks and the new ways of information classification created new challenges for the representation of digital information.

An important landmark in the use of the information architecture was the usage of websites that use of hyperlink as a way to access to information dynamically. Adopting hyperlink resource and various computational languages for the information outlining, as the ison and the $\mathrm{xml}$, as well the metadata, the representation and organization of the information started to work by technology and the internet. An important publication in the area was Ronsenfeld's, Morville and Arango book (20015) "Information Architecture for the World Wide Web and Beyond", which describes ways to dispose the information in an environment the websites and define the organization, labeling, navigation and search systems. 
The Information Architecture, used to aid in the creation the websites, manage the presentation and organization of these sites, however in the course of technological development and mobile devices (initially used only as the calendar function) that begun to incorporate too resources to visualization of websites. Beyond navigation functionality, many devices too began to have connections with internet to web access, so the smartphones become popular quickly.

The smartphone and the connection with the internet become popular quickly, being available between the more various social classes, massing access to mobile devices. Looking that scenery of popularization of the smartphones, moreover to web access and the applications, that are programs developed specifically for devices follow the same popularization movement. The relevance of applications is measured by the quantity of downloads and installations, being Brazil considered a phenomenon in use of smartphones applications, especially the ones with Android operational systems, present in $93 \%$ of smartphones in the country. The use of applications is extremely popular among the users, such as WhatsApp and Waze, which are quite used. Additionally some games listed between the most downloaded, as the Flappy Bird application, that became known by the speed of its success.

The Architecture of Pervasive Information theme uses the information technology allied with the Information Science to study environments whose information is present, $\underline{\text { in }}$ physical or digital environments.

For user support, the computational device have to make part of the environment and should be able to detect other computational devices to be a part of it. Of this interaction, arise the ability of computers act of "smart" way in our environment, full off by sensors and computational services.

In the universe of pervasive computational, many factors are important, such as hardware, software, users, telecommunications and diverse areas of human knowledge to make possible create rules and a modus operandi for the construction and the use of pervasive environments.

The information architecture provides ways to present information in interfaces to the user. For the architecture of pervasive information, the place where the information is present goes beyond the interface of computer, using all the possibilities of the physical environment such as the streets, constructions, natural spaces and other areas. In the same way as the computer becomes part of the environment, the Information Architecture follows this same characteristic and thus becomes pervasive. 


\section{Characterization of the research problem}

The arising of the internet has changed the ways of socialization and people's work. Born from a military research project of the 1950s, it had the objective of connect the most important research military centers in the United States to the headquarters known as The Pentagon. So was possible to exchange quickly and protected information in the role of research implicating nuclear technology (LIMA, 2000).

According Schleder and Silva (2011), Internet transformed the context as society communicates. The physical space it is not an obstacle to relationships and information transactions anymore.

At the beginning, Internet was limited to its use practically in mainframes; however, with the popularization of its access thanks to Tim Berners-Lee (the inventor of the World Wide Web) who created a simpler way of it in the 1990s. The web led the access on sites through a browser those entry web domains, sometimes difficult to remember known as Uniform Resource Locator (URL) popularly called as "Link". Following these same advances, the cellphones also started to access the web from the year 2000.

At that moment, the information architecture started to gain highlight as the way settings of the websites was popularized and begun to offer services through the sites interface. Similarly the cellphones commenced to offer access to those services that use interfaces full of with visual components to user interaction.

The advances caused by the adoption of interfaces full of visual components and the use of advanced graphics, converted the interaction way obtained through the internet (highlighting the available information in this interface) making necessary the creation of techniques to organize the accessed content. In this way the IA was studied the way as information its disposed and organized by computational interfaces, gain significance with the emergence attributed to web for access to information and data through the pages.

With the use of cellphones who became smartphones, the Information Architecture reaches a new level that goes into the physical environment and grow into consider moreover about computational interface therefore necessary to discover the Architecture of Pervasive Information.

In the other hand, the API goes beyond of internet. Are treated the informational framework as a whole linking digital and physical environments. To explore those environments the API proposes heuristic that deal with both environments, inquiring how "Pokémon GO" usage aspects of architecture of pervasive in the moment of user interaction? From the research problem are planed the objectives of analyses the 
surroundings presents on "Pokémon GO" considering the way as Architecture of Pervasive Information aspects are handled in the user interaction all along of the game play.

There were many motivations for the election of theme to be developed in the research for this dissertation. The contact with Information Architecture since graduation and it is linking with Information Science, are factors that make easier the search for explanations so cooperate to this area and for professional development.

It is important to note that Information Science goes through the moment of interactive knowledge that begun in 1995 to the present day. This interactive knowledge is linked to the usage of information and communication technologies, mainly through use of internet as explained by Barreto (2002, p. 72):

This moment has been identified beginning at 1990 to characterize that knowledge assumed a new status after Internet (specially the world wide web), even though the first efforts for a world wide web come out in 1972 with a public demonstration of Arpanet, which connected 40 computers (BARRETO, 2002, p. 72).

It is known that Internet made possible the advance in the Internet browsing through the web using graphical resources, making possible show and organize the information using the Information Architecture, and for integration with physical information environments to Architecture of Pervasive Information (API).

The API suffer too by the growing evolution that come with the technology. Within a short space of time (about seven years have passed) since the year 2010, when the thirdgeneration Internet connection was launched whose mobile connection became popular conform information published from the telecommunications industry. Today, the mobile connection is an integral part of the environment where smartphones are essentials for the API usage.

Another condition that motivates the research by architecture of pervasive information is the evolution in use of smartphones. An important data that reveal as the access to the web advanced through of mobile devices is the Facebook use (which according with data of Brazilian Institute of Geography and Statistics - IBGE and disclosed by the company itself) about 62 million people access Facebook every month in Brazil. Of these, about 50 million do through mobile devices. 
Despite recent, the information architecture lacks of researches that collaborate to development of an architecture of pervasive information, so that mobile devices start to offer us ways to go through of virtual space and become a single space mingling with the physical space around us.

Existing works such as the book "Pervasive Information Architecture: Designing Cross-Chanel User Experiences" by Italian authors Luca Rosati and Andrea Resmini suggest theoretical paths to creation of an architecture of pervasive information. Currently, several smartphones applications (including the example of "Pokémon GO") use numerous theories presents in Resmini and Rosati literature for bring a sensation of pervasive environment, using the digital and physical medium which are presented to users.

All these factors were decisive for the creation of this research. Every day it is more evident the creation of digital services that use information as center of its operation and this services use interfaces to transpose the virtual world and integrate with the real world.

\section{MATERIAL AND METHODS}

To achieve the objectives of this work and need of interaction between the researcher and the environment, usage of devices and applications involved, we opted for a participant type research, which will be of great relevance because it involve the researcher in the research object (SEVERINO, 2007)

For the investigation was used a smartphone to "Pokémon GO" execution, broadband $4 \mathrm{G}$ connection when available and another technological resources necessaries for its execution. For the development of the research, was sought locations considered "keys" in João Pessoa - Paraiba city, where could get a better perception of the game. The Table 1 detail the locations, heuristics by Resmini of Rosati (2011) and the points to be observed.

Table 1. Locations to use and test of application. Source: developed by the authors.

\begin{tabular}{cccc}
\hline & Local & Heuristic & Observed Point \\
\hline 1 & João Pessoa - PB & $\begin{array}{c}\text { Place-making Consistency Resilience } \\
\text { Reduction Correlation }\end{array}$ & $\begin{array}{c}\text { Interaction between physical } \\
\text { and digital environment }\end{array}$ \\
\hline 2 & João Pessoa - PB & $\begin{array}{c}\text { Organization Labeling Navigation } \\
\text { Search }\end{array}$ & Interface of Smartphone \\
\hline
\end{tabular}




\section{Informational environments and aspects of Architecture of Pervasive Information}

The Information Science is an area that use of inter/trans-disciplinary to realize studies about information, interacting with several human knowledge fields. This studies include too the digital nature of information, making possible to explore informational digital environments, full of information to use.

The information science emerge from a need in the face of concern about the amount of information produced and as this information will be created, stored, organized and distributed. For the understanding of Information Science moments and for further enrich the studies and the need of search information, the dynamic link theory discussed by the Belgian author Paul Otlet, in his book "Traité de Documentation"; which would be considered as the first concept that refers to the way internet works (OTLET, 1934; MUNDANEUM, 2013).

The search for models of information processing has been frantic since the midtwentieth century because at the end of World War II, exactly in July of 1945 the article "As We May Think" was published by the American engineer and scientist at MIT (Vannevar Bush) in which he referred to the concern about how the exponential growth of information produced after of World War II would be organized to be passed on to society (BUSH, 1945).

After that time, the technological revolution has profoundly changed the way as we relate to the information around us. For such, a new science emerge and comes to study the phenomena related to the information as a reference in the emerge of Information Science, as evidence (FREIRE, 2006)

We are living the contemporaneity or post-industrial age or information age, as was highlighted by Castells (1999), in which the technological revolution spreads throughout all areas of human knowledge and creates an evolution in information technology, changing the ways as people use information day by day. In this sense, Capurro (2003) highlights that IS has as main paradigm the study of mediation and use of information in all its forms of use, in different areas, in other sciences and contexts in addition to all their relationships.

During the production of his article, Vannevar Bush imagines a visionary mechanical machine called Memex, which will be used to aid human memory and keep knowledge safe. These could be dynamically associated as well as the human mind, therefore necessary to stock a large amount of information, since all along the time of publication of his article there was not an evolved mode to access and storage of the large amount of information which humanity would produce in the coming decades. 
Bringing to the present the idea of Memex, we can create an analog view to the dynamic association of ideas and knowledge, as well how hyperlinks work, used for the navigation on internet directories also known as web.

Knowing the history about Memex, and because it is something present in the most diverse areas of human knowledge, the information is something trivial in several daily activities: the information technology is based on this fact in order to develop the automation of the use of information for organizations and society in general, this is necessary at the moment that a lot of information is created at a speed never seen before. Borko (1968) alerted about this need, when asserted that would be necessary to provide an ambiance for the information that help organizations better cope with the streaming and remembrance of knowledge.

Following the evolution of society around information the IS developed many areas of study for information, an area of relevance which was studied is the representation of information, that according to Araujo (2009), became part of IS from the approach to librarianship.

It is also important to quote another crucial field of IS, that is used directly from the information representation, which is information recovery. Recovery systems work directly connected to the way as information is represented being part of the communication process involving, issuer, code, channel and receiver, in which the information will be emitted, represented by a code, transmitted by a channel, received and retrieved.

For the study of interfaces and users management, we must first give priority to the study of information, which is the raw material that connects users and interfaces.

For this study field the Information Science becomes indispensable because its source of studies is the information and every related aspects related to it (REES; SARACEVIC, 1967).

So, of study of information goes through several disciplines keeping the attention in information, and the position of Memex by Bush the IS was submitted to transformations and evolutions in the ways it carry out with studies about information and society. However, the great landmark of humanity in the use of information has been information and communication technology, which involves every single area of the human knowledge.

The web in its operation through hyperlinks, brought up the ideas of Vannevar Bush and Paul Otlet about word association that link to other and documents that transfer to others, which are a web upholder and key point for exploration of information representation (more specifically information architecture) through the use of computing devices connected to the 
network and operated by interfaces where the focal point is the information displayed and how the human being decodes and retrieves information in the form that it is represented.

In this way, IS and IA created an intersection between their areas of study as follows: "The IS corroborates the development of studies related to Information Architecture and user experience, which discuss and works with the three frequent paradigms in the study of these areas of knowledge" (PADUA, 2014, p. 27). To illustrate in which areas this occurs, the figure 1 addresses the areas of IS and IA where there is that occurrence.

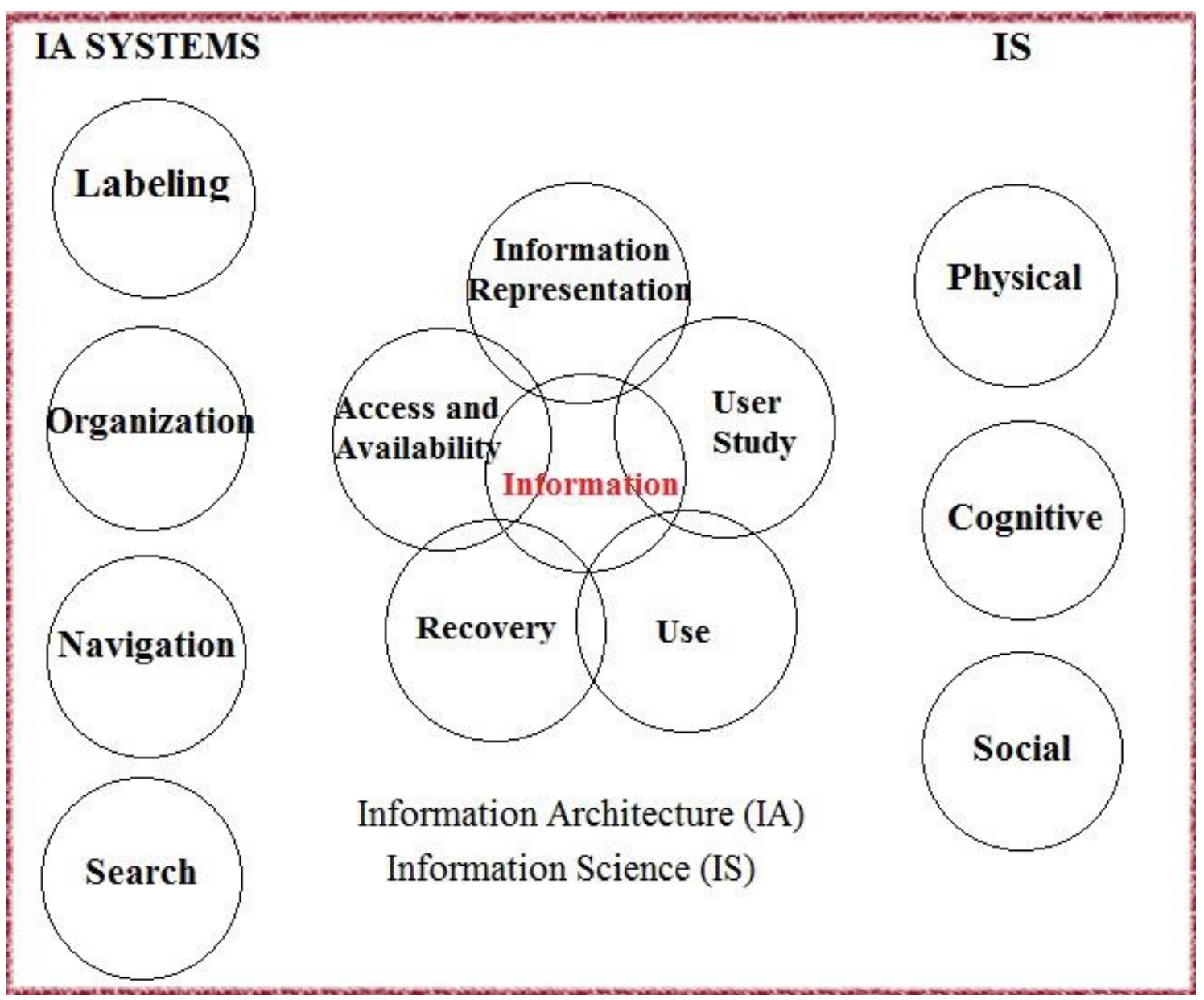

Figure 1. Intersection between the IS and the IA. Source: Based in Padua (2014, p. 27).

Thus, the IS became to aid in the advances of the studies about the IA and corroborate the advance in researches developed in the area, always attentive to technological developments, contexts and new social ways to handle the information and communication technologies. In this way, can cooperate with the researches about informational environments in the Architecture of Pervasive Information uses. 


\section{CONCLUSIONS}

The objectives defined for this research were achieved, wherein the used of methodological path was essential to the game play, even helping to collection and structuring of the data founded in heuristic application environments. After the discussion of results and the correlation with the theories was possible identify the positive and negative points, and made suggestions for a better user experience in immersion on the environment using the architecture of pervasive information.

So, it was identified how occurred the use of physical and digital spaces in a pervasive ways. For every moment of the game (in the pervasive environments), we observed the behavior according to the characteristics present in the heuristic. So, were identified the interfaces and the environments which integration between the physical and digital plan was completed, allowing to suggest improvements for the application of the pervasive heuristics described by Resmini and Rosati (2011).

By the need to investigate the pervasive environment some methodologies of scientific research were consulted, in which the participant research was used. Allied to the used of this methodology was important to have experience with the game (having completed two versions of Pokémon in 1999 and 2000) making possible to increase the focus on the architecture of the pervasive information present in the game.

Searching to something recent as "Pokémon GO" many possibilities for future researches are created, this study was of fundamental importance to advance in the investigation of pervasive environments, enriching and improving concepts and understandings of Information Science, especially in the studies and researches connected to Architecture of Pervasive Information. After of the game be used in many different environments for some days, the perceptions obtained were recorded and supported the evaluation of "Pokémon GO".

To analyze and collect data screenshots of moments representing every pervasive environment were used and each point has been evaluated as follow: Present, Partially Present and Not Present. The pervasive moments were obtained from the screens investigated, classified according to each heuristic in the form how every environment should behave.

During the discussion of the results was recognized that despite the innovative way as the game use the pervasive environment, employing the Augmented Reality to give to user the feeling of hybrid environment, characteristic present only in the capture of "Pokémon GO”, when used on a smartphone with adequate processing and memory is can also use the Augmented Reality all along the gym battles. To enhance user experience was suggested the 
use of technologies present on Google Maps as Street View and the satellite maps, thus creating an even more pervasive environment.

Another point observed during the discussion of this results is referring to the history experienced by the user in the game play which occurs in isolation, because is not interaction with other users for now, only with the Pokémon characters, even with the Pokémon characters belonging to the other users, however not with other users. Thus, is proposed the use of the pervasive environment in the creation of a multiplayer environment.

Using technologies already available and making the game even more fantastic in the operation of a pervasive environment, seeing that older editions of Pokémon it was possible to exchange Pokémon characters with other users.

During the development of the research, the methodology for analysis was based on the use of heuristics and Resmini and Rosati (2011) and Rosenfeld, Morville and Arango (2015). Within the Information Architecture and the Architecture of Pervasive Information no proposals were found for the creation of a specifically methodology for the evaluation of three-dimensional environments, using immersion through technology. As a suggestion, there are possibilities for future research aiming suggest specific approaches to pervasive environments. Using Augmented Reality and other technologies, there is the possibility of migration from hybrid environments to environments natively immersed between physical and digital.

The developer in future releases can implement the suggestions for better use of the pervasive environment present in "Pokémon GO". The architecture of the pervasive information must has its studies deepened taking in consideration which will be the new innovations to create environments immersed between physical and digital that can overcome the hybrid environments building an ecosystem of interconnected people, devices and society.

All along the bibliographic survey were founded articles about "Pokémon GO" whit different approaches such as advertising, geo-referencing, social aspects, tourism, among others. Thus, it is understood that possibilities in the exploration of several areas of study provided by the forms of used employed on "Pokémon GO" are practically limited. The Architecture of Pervasive Information despite working the integration of the environments about information should also include in is future studies, questions of interaction that possibly will be demonstrated when using holograms that use interaction with the user, when utilizing holograms the question of the interface become omnipresent.

All along the "Pokémon GO" game play, even using the Augmented Reality the experience is somewhat limited by the size of the smartphone screen. For the operation in 
other different scenarios of the Application, the ideas presented can be used for diverse commercial, academic and scientific purposes. Just that more technological advances, as the use of screens with higher resolution in smartphones and the usage of holograms so that the interaction can bring more pervasive experiences to users.

To greater technological advance, it will be possible to carry out more activities, for example, medical care with immersion in the patient's environment using holograms that allow interaction with doctors, patients, nurses and objects used during the medical procedure. Allowing feeling the "smells" of the environments, using the touch to feel the surfaces and integrating with the human senses. For interactive libraries and immersion within themes of books, current libraries must incorporate technological resources as Big Data and another technological element for interaction, where the library should function as an information center, in which it is possible to connect diverse informational sources using semantics through the internet.

\section{ACKNOWLEDGEMENTS}

This study was financed in part by the Coordenação de Aperfeiçoamento de Pessoal de Nível Superior - Brasil (CAPES) - Finance Code 001. I.S.B. thanks to the master's scholarship provided by CAPES. D.A.C. thanks to the doctoral scholarship provided by "Fundação de Apoio à Pesquisa do Estado da Paraíba" (FAPESQ) in partnership with CAPES. The authors thanks the facilities provided by the Universidade Federal da Paraíba (UFPB), Campus IV for the support to the realized research. Special thanks to Professor Dr. Marckson Barreto by the support for the orientation to this research.

\section{REFERENCES}

ARAÚJO, C. Correntes teóricas da ciência da informação. Ciência da informação, v. 38, n. 3, p. 192-204, 2009. Available at: http://www.scielo.br/scielo.php?pid=S010019652009000300013\&script=sci_abstract\&tlng=pt. Accessed on: 15 May 2018.

BARRetO, A.A. A condição da informação. São Paulo em Perspectiva, São Paulo, v. 16, n. 3, p. 67-74, 2002. Available at: http://www.scielo.br/scielo.php?script=sci_ arttext\&pid=S0102-88392002000300010. Accessed on: 16 May 2018.

BORKO, H. Information science: What is it? American Documentation, v. 19, n. 1, 1968. 
BUSH, V. As we may may think. Atlantic monthly, v. 176, n. 1, p. 112-124, 1945. Available at: http://worrydream.com/refs/Bush\%20-\%20As\%20We\%20May\%20 Think\%20(Life\%20Magazine\%209-10-1945).pdf. Accessed on: 11 May 2018.

CAPURRO, R. Epistemologia e ciência da informação. 2003. Available at: http:// www.capurro.de/enancib_p.htm. Accessed on: 16 May 2018.

CASTELLS, M. A sociedade em rede. 8. ed. São Paulo: Paz e Terra, 1999.

FREIRE, G.H. Ciência da informação: temática, histórias e fundamentos. Perspectivas em Ciência da informação, Belo Horizonte, v. 11, n. 1, p. 6-19. 2006. Available at: http://www.scielo.br/pdf/pci/v11n1/v11n1a02. Accessed on: 16 May 2018.

LIMA, F. O. A sociedade digital: o impacto da tecnologia na sociedade, na cultura, na educação e nas organizações. Rio de Janeiro: Qualitymark, 2000. 172 p.

MUNDANEUM. The origins of the Internet in Europe: collecting, indexing \& sharing knowledge. Exposição digital. [Projeto Google Arts \& Culture]. 2013. Available at: https://www.google.com/culturalinstitute/beta/exhibit/QQ-RRh0A?hl=pt-BR. Accessed on: 16 May 2018.

OTLET, P. Traité de documentation: le livre sur le livre, théorie et pratique. Bruxelas: Mundaneum, 1934. 480 p.

PADUA, M.C. Arquitetura da informação pervasiva e experiência do usuário: avaliando os ambientes informacionais do Proine. 2014. 239 f. Dissertação (Mestrado em Ciência da Informação) - Universidade Federal da Paraíba, João Pessoa, 2014.

REES, A.; SARACEVIC, T. Education for Information Science and its relation to librarianship. opus cit. p. 98, 1967.

RESMINI, A.; ROSATI, L. Pervasive information architecture: designing cross-channel user experiences. Burlington: Morgan Kaufmann, 2011a. 272p. 
ROSENFELD, L.; MORVILLE, P.; ARANGO, J. Information architecture: for the web and beyond. Sebastopol: O'Reilly Media, 2015. 486 p.

SCHLEDER, V; SILVA, D. O uso da internet como uma ferramenta de marketing de relacionamento nas agências de comunicação de Santa Maria-RS. Iniciacom, v. 2, n. 2, 2010. Available at: http://portcom.intercom.org.br/revistas/index.php/iniciacom/ article/view/691/627. Accessed on: 15 May 2018.

SEVERINO, A.J. Metodologia do trabalho científico. São Paulo: Cortez, 2007. 304 p.

WURMAN, R.S. Information architects. 2. ed. Lakewood: Watson-Guptill Pubns, 1997. $235 \mathrm{p}$. 